\title{
The Effect of Terrorist Incidents on the Occupational Attitude of Teachers
}

\author{
Ahmet Üstün \\ Department of Educational Sciences, Education Faculty, Amasya University, Turkey
}

Copyright $(02016$ by authors, all rights reserved. Authors agree that this article remains permanently open access under the terms of the Creative Commons Attribution License 4.0 International License.

\begin{abstract}
This study examined how many terrorist incidents affected the teachers' occupational attitude by the variables of gender, marital status, birthplace, the term of employment and occupational status with "the effect of terrorist incidents on the occupational attitude of the teacher" scale. In this study, descriptive scanning method among quantitative research methods was employed. The sample of the research was determined by the simple random sampling selection among the probabilistic sampling choices, and it consisted of 116 teachers who served in Bulan1k district of Muş Province during the 2015-2016 academic year. In the analysis of the data, arithmetic mean, frequency, percentage, t-test, ANOVA and Turkey tests were employed. The levels of being affected by terrorist incidents in the occupational sense of the teachers who participated in the study were found to be at the medium level. While significant differences were not observed according to the gender, marital status and occupational status of the teachers, significant differences were determined according to their birthplaces and term of employment. As a result of the study, it was suggested to provide in-service training to improve the occupational attitudes of the teachers serving in a terror zone in the positive direction.
\end{abstract}

Keywords Attitude, Occupation, Teacher, Terror

\section{Introduction}

Terror comes as one of the primary problems which occupy the agenda in the world and in our country. The terror which increasingly continues all over the world after the attacks made to the World Trade Center and Pentagon in the history of the USA on 11 September 2001 have recently occurred in Germany, France, Belgium and especially in our country, and many people lost their lives during these terrorist incidents. It is understood from this situation that terror is not a national problem but an international one.

The concept of terror has not been internationally defined, and it has been attempted to give different definitions to it depending on the characteristic of its area. Some of these definitions are as follows;

Terror is defined as "murder, ravage, sabotage, abduction, robbery and suchlike planned intentional activities carried out by illegal organizations with the purpose to bring the enemy, neutral foreign societies, ally groups under influence, assimilate them, and bring them into their folds". Terror is defined as "the use of violence against political corporations or the use of violence with the purpose of terrorizing various sections of the public" in the English Anti-terrorism legislation; and as "any activity participated individually or collectively with the purpose to seriously disturb the public peace by means of oppression or threat" in the French Anti-terrorism legislation [1].

In Turkey, the $1^{\text {st }}$ article of the anti-terrorism law enacted on 12.04.1991 defines terror as follows.

"Terror is defined as; any kind of activity that
constitutes a crime, which is conducted by a person or
persons who are members of an organization with the
purpose of changing the qualities, political, juridical,
social, secular, and economic order of the Republic
stated in the Constitution, disrupting the integrity of
the State with the country and nation, threatening the
existence of the Turkish State and Republic,
debilitating or demolishing or capturing the authority
of the State or demolishing the basic rights and
liberties, disturbing the internal and external security,
public order or general health of the State by pressure,
threatening, terrorization, suppression or one of the
methods of threatening." [2]

By setting off from the definitions given in regard to the concept of terror, it is understood that terrorist the activities performed by the organizations which disturb the unity and solidarity of the countries, threaten the unity of the state, lead to the loss of lives and property of people, and consider that they are legible to obtain some political, economic and religious purposes by force. Since it is not known when and where a terrorist incident will occur, it causes people to worry. People in the places where terrorist incidents take place more frequently have to continue their daily lives in 
fear. This situation shows that although people are not directly exposed to terrorist incidents, they are psychologically terror victims. Terrorist incidents are not only military, police-targeting situations, they also include the actions carried out especially against schools where children receive an education. While terrorist incidents carried out against schools affect students, they also affect teachers as well.

A teacher is simply a person who conducts the act of education. While performing the act of education, the teacher has to prepare the suitable environment, know the necessary methods and techniques and apply them for the student to learn meaningfully and permanently and should be as eager to learn as the student is. As his occupation requires, the teacher needs to improve and adapt himself in every subject. This improvement should not only be in the field knowledge but also in social and affective fields as well.

As Mustafa Kemal Ataturk stated in his addressing to the teachers, "Two armies are necessary to make our land, our society achieve real goal, real happiness. One of them is the army of soldiers who save the life of this country and another one is the army of knowledge shaping the future of the country." As it was in the past, today too, education is one of the most important needs of the humanity. The most important and indispensable element of the education system is the teacher. According to Kavcar [3], the success of the education system depends on the qualities of the teachers who will manage and apply the system and other education personnel. No education model can produce any service which is above the quality of the personnel who will operate that model.

According to Demirel [4], qualities of a teacher are divided into two as personal qualities and occupational qualities. Upon examining these studies, it is seen that one of the most important factors affecting the qualities is the occupational attitude of an individual.

Attitude is defined as the kind of behavior an individual takes in front of people, events, and inanimate entities. The elements comprising the attitude are examined under three main topics. These are cognitive, behavioral, and emotional elements. The cognitive element is the total of the belief, thought and information about the event, person or the object which are the subject of the attitude [5]. This element consists of the reactions a person gives depending on the situations he faces and his/her experiences. The behavioral element expresses the behavioral tendency of a person in front of a stimulus. The emotional and canonical dimensions lying in the base of the behavioral element affect each other directly and are addressed as a whole. The emotional element can be defined as positive-negative, desired-undesired reactions of an individual against any situation, event, person. This element cannot be considered independently from the behavioral and cognitive dimensions. While the experiences of a person, and a cognitive element which is the knowledge accumulation directly affect the development of the emotional element, the person has to have previously experienced the positive and negative reactions that he will give to any event or situation and this is possible with the behavioral element.

The effect of the attitude in the teaching profession on students is quite big. At this point, some researchers have taken attentions the effects of teacher education on student learning and achievement $[6,7,8]$. The teachers' occupational attitudes are affected by the socio-cultural and economic structure of their environment, the sufficiency of the occupational education they have received, the communication with the school personnel and administration, natural and human events occurring in the environment.

In our country as well, the terrorist incidents experienced in some regions affect the teachers' lives directly. During the terror incidents densely experienced in the $90 \mathrm{~s}$, lives of many teachers were claimed by the terrorist organization. On April 16, 1990, 4 teachers in Elazığ, on September 1, 1994, 6 teachers in Tunceli Darıkent, on April 23, 1996, 3 teachers in Ekinöz district of Kahramanmaraş and a total of 143 teachers were martyred in various provinces in the region [9] Along with this, events such as teacher abduction, attacks made against schools caused disruptions in the education for a while [10].

With the recently increasing terrorist incidents in our country, actions such as teacher abduction, burning schools, etc. are experienced. With these actions, schools were rendered unusable, and the education of the students who need to receive an education was hindered. Closing up the shops, application of curfews due to terror, conflicts of the terrorist organization members with the police and soldiers, exploding vehicles by planting mines on the roads, attacks against public buildings experienced in some regions also affect the daily life negatively and cause the social activities to be hindered. As it is stated above, we indicated that the occupational attitudes of the teachers are affected by the environment to a significant extent. All these events occurring negatively affect the occupational attitude of the teachers. Terrorist incidents cause teachers to think of the security of their lives more than the education activities.

For this reason, it is necessary to know how much teachers working in the regions called a terror zone are affected by terrorist incidents, thoughts of teachers in the region where terrorist incidents frequently occur to contribute to the studies to be performed to improve and develop the quality of education and training in the region.

\subsection{The Objective of the Study}

In this study, it was attempted to present "The Effect of Terrorist Incidents on the Attitude of Teaching Profession" to the teachers who serve in Bulanık district of Muş province named as a terror zone.

\subsection{Problem Statement}

Do terror incidents have any effect on the occupational 
attitude of the teachers?

\subsection{Sub-problems}

- Do the point averages of the terror incidents regarding the occupational attitude of the teachers vary by gender?

- Does the effect of terrorist incidents on the occupational attitude of the teachers vary by the marital status?

- Does the effect of terrorist incidents on the occupational attitude of the teachers vary by the birthplace?

- Does the effect of terrorist incidents on the occupational attitude of the teachers vary by the term of employment?

- Does the effect of terrorist incidents on the occupational attitude of the teachers vary by the occupational status?

\section{Method}

This research is a descriptive study of the scanning model among the quantitative research methods. The data were collected with the survey method to determine the effect of terrorist incidents on the attitude of the teaching profession.

\subsection{Sample}

It consists of 116 teachers working in Bulanık district of Muş Province in the 2015-2016 academic year, 73 of whom are females and 43 are males. In the sample selection, the simple random sample method among the probabilistic sampling selection was employed. The simple random sampling is a sampling method in which the chance of being selected for all individuals in the universe is equal. This sampling method is known as a simple, easy, and reliable method which is accepted to be at the mid-good level in terms of validity and reliability [11].

\subsection{Data Collection Tool}

The research data were obtained through the teaching profession attitude scales prepared before as a result of the literature review performed by the researcher $[12,13,14,15$, $16]$ and through the 5-point Likert-type scale consisting of 20 questions prepared by taking the expert opinion. The grading of the measuring tool is as Strongly agree $=5$, Agree $=4$, Neutral $=3$, Disagree $=2$, Strongly disagree $=1$. The alpha reliability coefficient of the measuring tool was found to be .906 , and the KMO value was found to be .866 .

\subsection{Data Analysis}

The data obtained from the study were analyzed by using SPSS (V.17). In the analysis of the data, the frequency, and percentages, arithmetic mean were used, the t-test and one-way analysis of variance (ANOVA) were used for the independents groups, and the Tukey test techniques were used to determine upon which groups the differences were. In order to interpret the results, the significance level of $\mathrm{p}<0.05$ was benefited from. 


\section{Findings, Interpretation and Discussion}

Table 1. Values related to the attitude scores obtained by the teachers from the scale.

\begin{tabular}{|c|c|c|c|c|c|c|}
\hline $\mathrm{N}$ & & Min & Max & \multicolumn{3}{|c|}{ SD } \\
\hline 116 & 3.32 & 1.50 & 4.70 & \multicolumn{3}{|c|}{0.71} \\
\hline \multicolumn{4}{|c|}{ Effect of terrorist incidents on the teaching profession attitude } & $\mathrm{N}$ & & SS \\
\hline \multicolumn{4}{|c|}{$\begin{array}{l}\text { 1- After having worked in the region where terrorist incidents occurred, the number of suggesting my } \\
\text { profession to people around me decreased. }\end{array}$} & 116 & 2.95 & 1.41 \\
\hline \multicolumn{4}{|c|}{ 2- Because of the terrorist incidents, I feel uneasy when I enter or exit school. } & 116 & 3.08 & 1.33 \\
\hline \multicolumn{4}{|c|}{ 3- That the first place I was appointed to was a terror zone made me feel anxious. } & 116 & 3.87 & 1.24 \\
\hline \multicolumn{4}{|c|}{ 4- I think that terrorist incidents negatively affect students in the affective aspect. } & 116 & 4.00 & 1.11 \\
\hline \multicolumn{4}{|c|}{ 5- I do not find the lodgments safe in the areas where terrorist incidents occur. } & 116 & 4.04 & 0.93 \\
\hline \multicolumn{4}{|c|}{ 6- Due to the terrorist incidents, I'm thinking of using my appointment right at the earliest opportunity. } & 116 & 3.74 & 1.26 \\
\hline \multicolumn{4}{|c|}{ 7- I think terror incidents limit my social activities. } & 116 & 4.41 & 0.80 \\
\hline \multicolumn{4}{|c|}{ 8- I think that terrorist incidents kill my occupational passion. } & 116 & 3.33 & 1.30 \\
\hline \multicolumn{4}{|c|}{ 9- Terrorist incidents affect my communication with the public negatively. } & 116 & 3.44 & 1.27 \\
\hline \multicolumn{4}{|c|}{ 10- Terrorist incidents hinder my self-development in terms of profession. } & 116 & 3.15 & 1.30 \\
\hline \multicolumn{4}{|c|}{ 11- I'm thinking of resigning due to terrorist incidents. } & 116 & 1.57 & 0.74 \\
\hline \multicolumn{4}{|c|}{ 12- Negative news coming from the region decrease my effectiveness in the class. } & 116 & 2.99 & 1.24 \\
\hline \multicolumn{4}{|c|}{ 13- I believe that terrorist incidents decrease the sentimental value I get from the profession. } & 116 & 3.26 & 1.26 \\
\hline \multicolumn{4}{|c|}{ 14- I think that terrorist incidents hinder me from performing my job professionally. } & 116 & 3.09 & 1.20 \\
\hline \multicolumn{4}{|c|}{ 15- I regret having chosen the teaching profession due to the terror and conflict environment. } & 116 & 2.02 & 1.14 \\
\hline \multicolumn{4}{|c|}{ 16- The teaching profession is not sufficiently valued in the region. } & 116 & 2.69 & 1.33 \\
\hline \multicolumn{4}{|c|}{ 17- The attacks made against schools make me anxious. } & 116 & 4.00 & 1.07 \\
\hline \multicolumn{4}{|c|}{ 18- The casualty news coming from the region decrease my occupational motivation. } & 116 & 4.01 & 1.07 \\
\hline \multicolumn{4}{|c|}{$\begin{array}{l}\text { 19- I feel anxious during the going and comings to the invigilation (TEOG, Open education examination, etc.) } \\
\text { duty places in the region. }\end{array}$} & 116 & 3.26 & 1.23 \\
\hline \multicolumn{4}{|c|}{ 20- I feel anxious about the terrorist incidents which are likely to occur during the watch duty. } & 116 & 3.48 & 1.18 \\
\hline
\end{tabular}

After carrying out the analysis of the data, the arithmetic mean of the replies given to all the questions was found to be $\bar{X}=3.32$. Also, while the minimum value obtained from the scales was $\bar{X}=1.50$, the maximum value was calculated as $\bar{X}=4.70$. The standard deviation of the scale is 0.71 . Upon examining it on the question basis, the lowest average with $\bar{X}=1.57$ is the $11^{\text {th }}$ question (I'm thinking of resigning due to terrorist incidents). Although terrorist incidents affect teachers in every aspect, the resigning option is not attractive to teachers. As a reason for this, financial impossibilities and commitment to the teaching profession can be presented. The question with the highest average is the $9^{\text {th }}$ question with $\bar{X}=3.44$ (Terrorist incidents limit my social activities). The reason for the social activities being limited can be indicated as the investments which are not done due to terrorist incidents and the danger of going out after certain hours. "In the teacher's success in the class, social sufficiency is more effective than his technical sufficiency. It enables the teacher to accept the students the way they are, to communicate with them in a proper way, and enables the students to learn and attain high success" [17]. The lack of conditions also decreases the possibility of attaining high success.

Another remarkable statistic is encountered in the question 15. (I regret having chosen the teaching profession due to the terror and conflict environment). The average of the replies given to the question is 2.02 which corresponds to the disagree option. According to this result, it can be concluded that teachers do their jobs very fondly and their occupational attitudes are high.

\subsection{Regarding the First Sub-Problem}

Table 2. Participants' distribution by gender.

\begin{tabular}{ccc}
\hline Gender & Frequency & $\%$ \\
\hline Female & 73 & 62,93 \\
Male & 43 & 37,07 \\
\hline
\end{tabular}

As it is seen from Table 2, $62.93 \%$ of the participants consist of females and $37.06 \%$ of them consist of males. If these rates are considered to be similar to the district-wide distribution, it can be said that "results supporting the general estimation that teaching profession is regarded as a female profession and selections are made accordingly are 
obtained" [18].

Table 3. Difference of scale points by gender.

\begin{tabular}{cccccc}
\hline Gender & $\mathrm{N}$ & & $\mathrm{SD}$ & $\mathrm{t}$ & $\mathrm{p}$ \\
\hline Female & 73 & 3.41 & 0.67 & & \\
& & & & 1.908 & 0.059 \\
Male & 43 & 3.16 & 0.74 & & \\
\hline
\end{tabular}

In order to determine whether there are significant differences according to the gender of the participants in the effect of terrorist incidents on the teaching profession attitude scale, the " $\mathrm{t}$ " test was carried out. In the " $\mathrm{t}$ " test carried out, it was found as $\bar{X}=3.41$ for females and $\bar{X}=3.16$ for males, and the p-value was found to be 0.059 . However, since this value does not meet the $p<0.05$ requirement, no significant difference between the attitudes of female and male teachers was found. This result was also found in some other researches which studied the teachers' occupational attitudes $[19,20]$.

However, when the questions were analyzed individually, some significant differences were determined. There are given in table 4.

Table 4. Questions and values showing significant differences by gender

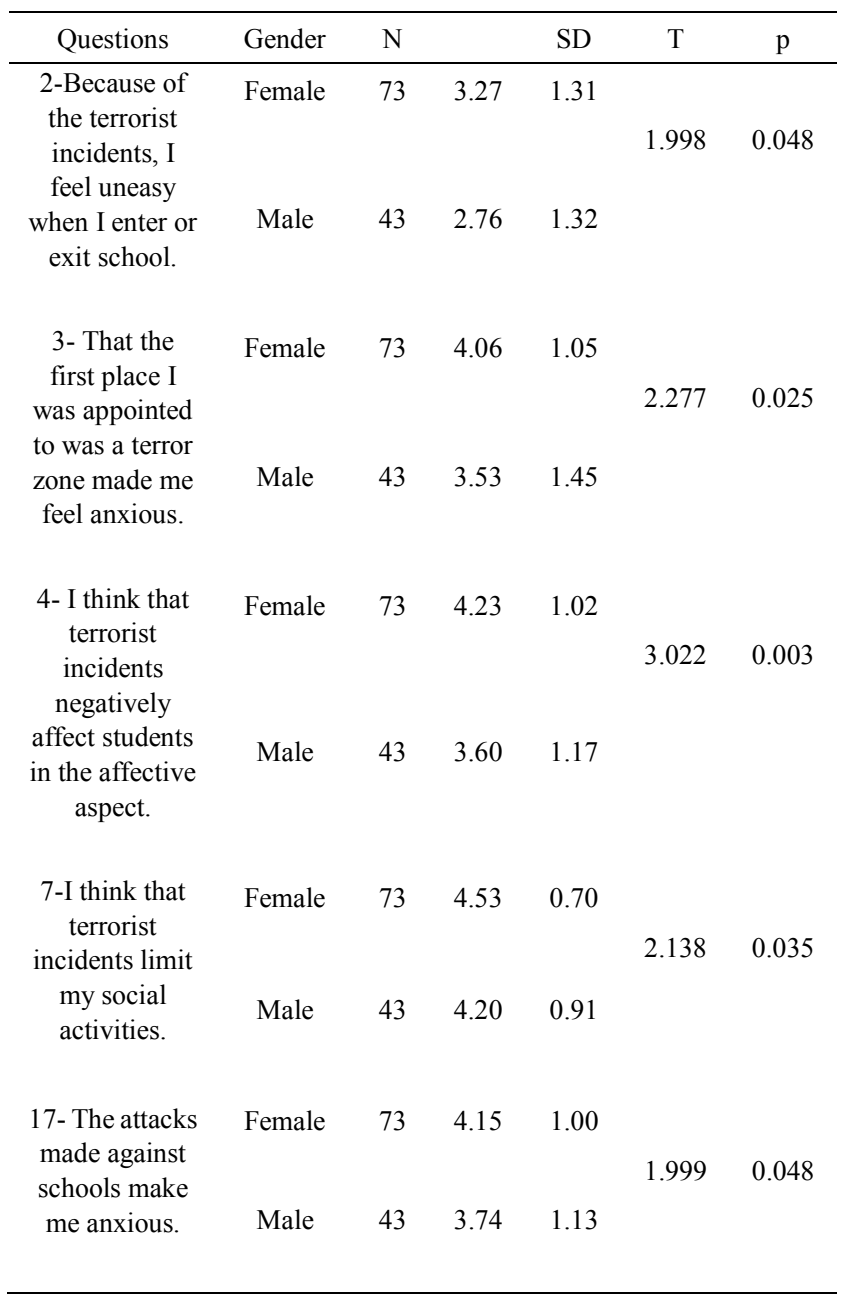

In the questions given in Table $4, \mathrm{p}<0.05$ significance value was ensured. When the arithmetic means for each question were examined, it was observed that females had a higher average than males. In this case, it can be concluded that female teachers are more affected by terrorist incidents when compared to male teachers.

\subsection{Findings, Interpretation and Discussion Related to the Second Sub-Problem}

Table 5. Distribution of the participants by marital status.

\begin{tabular}{ccc}
\hline Marital Status & Frequency & $\%$ \\
\hline Single & 79 & 68,10 \\
Married & 37 & 31,89 \\
\hline
\end{tabular}

As it is seen from Table 5 , while $68.10 \%$ of the teachers participating in the study were single, $31.89 \%$ of them were married.

Table 6. Difference of the scale points by marital status.

\begin{tabular}{cccccc}
\hline $\begin{array}{c}\text { Marital } \\
\text { Status }\end{array}$ & $\mathrm{N}$ & $\bar{X}$ & $\mathrm{SD}$ & $\mathrm{t}$ & $\mathrm{p}$ \\
\hline Single & 79 & 3.39 & 0.66 & & \\
& & & & 1.574 & 0.118 \\
Married & 37 & 3.17 & 0.78 & & \\
\hline
\end{tabular}

In the effect of terrorist incidents on the teaching profession attitude scale the t-test was applied to determine whether there was a significant difference depending on the marital status of the research participants. In the t-test carried out, $\bar{X}=3.39$ was found for the singles, $\bar{X}=3.17$ was found for the married, and the p-value was found to be 0.118 . However, since this value did not meet the $\mathrm{p}<0.05$ value, a significant difference between the attitudes of the married and single teachers was not found. This result shows parallelism with other articles investigating the similar subject [21, 22].

However, when the questions were individually analyzed, some significant differences were found. These questions are presented in Table 7.

Table 7. Questions and values showing significant difference by marital status.

\begin{tabular}{ccccccc}
\hline Questions & $\begin{array}{c}\text { Marital } \\
\text { Status }\end{array}$ & $\mathrm{N}$ & $\bar{X}$ & $\mathrm{SD}$ & $\mathrm{t}$ & $\mathrm{p}$ \\
\hline $\begin{array}{c}\text { 13-I believe that } \\
\text { terrorist } \\
\text { incidents } \\
\text { decrease the } \\
\text { sentimental } \\
\text { value I get from } \\
\text { the profession. }\end{array}$ & Single & 79 & 3.46 & 1.21 & & \\
$\begin{array}{c}\text { 14- I think that } \\
\text { terrorist } \\
\text { incidents hinder } \\
\text { me from } \\
\text { performing my } \\
\text { job }\end{array}$ & Single & 79 & 3.25 & 1.19 & & \\
$\begin{array}{c}\text { job } \\
\text { professionally. }\end{array}$ & Married & 37 & 2.75 & 1.16 & & \\
\hline
\end{tabular}

The $p<0.05$ significance value was ensured in the 
questions given in Table 7. When the arithmetic means for each question are examined, it is observed that single teachers have a higher average than the married ones. In this case, it can be concluded that single teachers are more affected by terrorist incidents than the married teachers.

\subsection{Findings, Interpretation, and Discussion Regarding the Third Sub-problem}

Table 8. Distribution of the participants by the birthplace

\begin{tabular}{ccc}
\hline Region & Frequency & $\%$ \\
\hline Marmara Region & 11 & 9.48 \\
Aegean Region & 17 & 14.65 \\
Black Sea Region & 18 & 15.51 \\
Central Anatolia Region & 27 & 23.27 \\
Mediterranean Region & 25 & 21.55 \\
Eastern Anatolia Region & 12 & 10.34 \\
Southeastern Anatolia & 6 & 5.17 \\
Region & 6
\end{tabular}

As it is seen from Table 8, 9.48\% of the participants were born in the Marmara, $14.65 \%$ of them were born in the Aegean, $15.51 \%$ of them were born in the Black Sea, $23.27 \%$ of them were born in the Central Anatolia, 21.55\% of them were born in the Mediterranean, $10.34 \%$ of them were born in the Eastern Anatolia, and 5.17\% of them were born in the Southeastern Anatolia Region.

Table 9. Difference of the scale points by the birthplace

\begin{tabular}{|c|c|c|c|c|c|c|}
\hline Birthplace & $\mathrm{N}$ & $\mathrm{X}$ & $\mathrm{SD}$ & $\mathrm{F}$ & $\mathrm{p}$ & $\begin{array}{c}\text { Difference } \\
\text { (Tukey) }\end{array}$ \\
\hline $\begin{array}{l}\text { 1.Marmara } \\
\text { Region }\end{array}$ & 11 & 3.46 & 0.57 & & & $\begin{array}{c}1 \text { to } 6 \text { and } \\
7\end{array}$ \\
\hline $\begin{array}{l}\text { 2.Aegean } \\
\text { Region }\end{array}$ & 17 & 3.61 & 0.67 & & & $\begin{array}{c}2 \text { to } 6 \text { and } \\
7\end{array}$ \\
\hline $\begin{array}{l}\text { 3.Black Sea } \\
\text { Region }\end{array}$ & 18 & 3.68 & 0.53 & & & 3 to 6 and 7 \\
\hline $\begin{array}{c}\text { 4.Central } \\
\text { Anatolia Region }\end{array}$ & 27 & 3.38 & 0.58 & 6.996 & 0.000 & 4 to 6 and 7 \\
\hline $\begin{array}{l}\text { 5.Mediterranean } \\
\text { Region }\end{array}$ & 25 & 3.31 & 0.69 & & & 5 to 7 \\
\hline $\begin{array}{c}\text { 6.Eastern } \\
\text { Anatolia Region }\end{array}$ & 12 & 2.67 & 0.60 & & & $\begin{array}{l}6 \text { to } 1,2,3 \\
\text { and } 4\end{array}$ \\
\hline $\begin{array}{l}\text { 7.Southeastern } \\
\text { Anatolia Region }\end{array}$ & 6 & 2.25 & 0.58 & & & $\begin{array}{c}7 \text { to } \\
1,2,3,4 \\
\text { and } 5 \\
\end{array}$ \\
\hline
\end{tabular}

The one-way analysis of variance (ANOVA) test was applied to determine whether there were significant differences depending on the birthplace of the research participants in the effect of terrorist incidents on the teaching profession attitude scale. The Tukey test was carried out to determine between which groups the difference was present.

As it is seen from Table 9, significant differences were detected in the effect of terrorist incidents on the teaching profession attitude scale depending on the birthplace. While the region which is most affected by terrorist incidents is those born in the Black Sea Region with $\bar{X}=3.68$, the least affected are those born in the Southeastern Anatolia Region with $\bar{X}=2.25$. It is rather significant that those born in the Eastern and Southeastern Anatolia Regions with the lowest influence rates are represented with the lowest rate. Significant differences were found between the Marmara Region and Eastern and Southeastern Anatolia Region, between the Aegean Region and Eastern and Southeastern Anatolia Region, between the Black Sea Region and Eastern and Southeastern Anatolia Region, between the Central Anatolia Region and Eastern and Southeastern Anatolia Region, between the Mediterranean Region and Southeastern Anatolia, between the Eastern Anatolia Region and Marmara, Aegean, Black Sea and Central Anatolia Regions, between the Southeastern Anatolia Region and Marmara, Aegean, Black Sea, Central Anatolia and Mediterranean Regions. Based on these findings, it was observed that the effect of terrorist incidents on the teaching profession attitude for the teachers who come from the regions where terrorist incidents occur less is more, while those born in the Eastern and Southeastern Anatolia Regions were terrorist incidents occur more frequently are less affected by the terrorist incidents in terms of the occupational attitude. As a reason for observing these differences, it is considered that individuals become more immune to the events where terrorist incidents occur more frequently, yet, as the teachers who come from the outside of the region encounter such incidents less frequently or have never encountered them, they might show a more anxious approach to the incidents.

\subsection{Findings, Interpretation, and Discussion Regarding the Third Sub-problem}

Table 10. Distribution of the participants by the term of employment.

\begin{tabular}{ccc}
\hline Term of Employment & Frequency & $\%$ \\
\hline 1-3 Years & 93 & 80,17 \\
4-7 Years & 15 & 12,93 \\
8-10 Years & 4 & 3,44 \\
11-15 Years & 2 & 1,72 \\
16 Years and Above & 2 & 1,72 \\
\hline
\end{tabular}

As it is seen from Table $10,80.17 \%$ of the teachers in our sample have been practicing the teaching profession for between $1-3$ years, $12.93 \%$ of them for between $4-7$ years, $3.44 \%$ of them for $8-10$ years, $1.72 \%$ of them for $11-15$ years, and $1.72 \%$ of them for 16 years and more.

Table 11. Difference of the scale points by the teachers' term of employment.

\begin{tabular}{ccccccc}
\hline $\begin{array}{c}\text { Term of } \\
\text { Employment }\end{array}$ & $\mathrm{N}$ & & $\mathrm{SD}$ & $\mathrm{F}$ & $\mathrm{p}$ & $\begin{array}{c}\text { Difference } \\
(\text { Tukey }) \\
\mathrm{p}<0.05\end{array}$ \\
\hline $\begin{array}{c}\text { 1-3 Years } \\
\text { 4-7 Years }\end{array}$ & 15 & 3.40 & 0.68 & & & \\
8-10 Years & 4 & 3.26 & 0.24 & 3.743 & 0.007 & $\begin{array}{c}1-3 \text { Years } \\
\text { and } 11-15 \\
\text { Years }\end{array}$ \\
$\begin{array}{c}\text { 11-15 Years } \\
\text { 16 Years and } \\
\text { Above }\end{array}$ & 2 & 1.90 & 0.35 & & & \\
\hline
\end{tabular}

As it is seen from Table 11, the teacher group which is 
most affected by terrorist incidents is those who have worked for $1-3$ years with $\bar{X}=3.40$, and the least affected group is the teachers who have worked for11-15 years with $\bar{X}=1.90$.

The one-way analysis of variance (ANOVA) was applied to determine whether there was a significant difference in the effect of terrorist incidents on the teaching profession attitude scale according to the term of employment of the participants. The $p=0.007$ value ensured the $p<0.05$ significance value. According to this, there is a significant difference between the groups. The Tukey test was applied to determine between which groups the difference was present. According to the result, the significant difference was detected only between those who have worked for 1-3 years and those who have worked for 11-15 years. Similar results were also found in different studies [21,22, 23]. However, upon examining the table, as it can be seen, the hypothesis that the effect of terrorist incidents on the teaching profession attitude decreases as the term of employment increases is wrong. That the number of people is not homogeneously distributed among the groups can be given as the reason for this. Moreover, it can be concluded that as the group who has worked for 1-3 years is excess and others are less in number, the teachers come to the western regions from the eastern regions where terrorist incidents are more frequent by the spouse-related appointment right, and consequently, there are not many experienced teachers in the east. It can be said that this situation negatively affects the quality of the education-training in the eastern provinces where terrorist incidents frequently occur.

\subsection{Findings, Interpretation and Discussion Related to theFifth Sub-problem}

Table 12. Distribution of the participants by the occupational status.

\begin{tabular}{ccc}
\hline Occupational Status & Frequency & $\%$ \\
\hline Principal & 6 & 5,17 \\
Vice-principal & 7 & 6,03 \\
Teacher & 103 & 88,79 \\
\hline
\end{tabular}

As it is seen from Table 12, 5.17\% of the participants' occupational status consist of the principals, $6.03 \%$ consist of vice-principals, and $88.79 \%$ of them consist of teachers.

Table 13. Difference of the scale points by the occupational status.

\begin{tabular}{cccccc}
\hline Occupational Status & $\mathrm{N}$ & & $\mathrm{SD}$ & $\mathrm{F}$ & $\mathrm{p}$ \\
\hline Principal & 6 & 3.12 & 0.95 & & \\
Vice-principal & 7 & 3.06 & 0.81 & 0.786 & 0.458 \\
Teacher & 103 & 3.35 & 0.69 & & \\
\hline
\end{tabular}

The one-way analysis of variance (ANOVA) was applied to determine whether the participants showed a significant difference according to their occupational status in the effect of terrorist incidents on the teaching profession attitude scale, and $\mathrm{p}=0.458$ was found. Since this result did not meet the $\mathrm{p}<0.05$ significance value, any significant difference between the statuses was not determined. The averages obtained from the scales were found as; $\bar{X}=3.12$ for principals, $\bar{X}=3.06$ for vice-principals and $\bar{X}=3.35$ for teachers. That the values turned out to be close to each other shows that the executives show the same attitude with the teachers.

\section{Conclusions and Suggestions}

\subsection{Conclusions}

In this study in which we aimed to determine whether there were significant differences according to the gender, marital status, birthplaces, terms of employment, and status of the teachers serving in Bulanık district of Muş province with the effect of terrorist incidents on the teaching profession attitude scale, the following results were achieved.

The effect of terrorist incidents on the teaching profession attitude turned out to be at the middle level. As the reasons for this, that recently there has not been any incident aimed at teachers in the terrorist attacks in Bulanık district of Muş province, that the incidents occur at definite hours, that the public warn teachers before an incident occurs and keep them out of the incidents can be shown.

The effect of terrorist incidents on the teaching profession attitude did not show a significant difference according to gender, and the averages of being affected by terrorist incidents in terms of occupation of female and male teachers turned out to be close to each other. A result which contradicts with the opinion in the public that women are more afraid of the actions which contain violence or are more affected by them was obtained. However, a significant difference emerged in some questions, and the questions in which difference emerged were specified in the study.

The effect of terrorist incidents on the teaching profession attitude did not show any significant difference according to the marital status, and single and married teachers' being affected by terrorist incidents in terms of occupation turned out to be close to each other.

The effect of terrorist incidents on the teaching profession attitude showed significant differences according to the birthplaces. This difference emerged especially between the teachers who were born in the Eastern and Southeastern Anatolia Regions and those coming from other regions. It was observed that teachers who were born in the Eastern and Southeastern Anatolia Region were little affected by terrorist incidents in terms of occupation. As a reason for this, it can be said that aforementioned teachers have been exposed to similar terrorist incidents for many years and got used to this situation, and also as their communication with the public is much healthier, they feel secure and are less affected by the incidents. As a reason for why teachers coming from other regions are more affected by terrorist incidents in terms of their occupational attitude, that they have encountered 
terrorist activities less or have not encountered them at all during their lives, that they have difficulty in adapting to a different culture and different language can be given.

The effect of terrorist incidents on the teaching profession attitude showed significant differences by the term of employment. This difference emerged between teachers who have worked for 1-3 years and those who have worked for 11-15 years, a difference between other groups did not emerge. As a reason for this result, that $80.17 \%$ of the participants were in the group working for 1-3 years and the rest $20 \%$ were distributed among the other groups, thus the teachers who have worked for 4-7, 8-10,11-15 and 16 and more years were not reached can be given. The reason for not being able to reach the teachers who have worked for a long time can be shown as that the teachers ask for their appointment after fulfilling their obligatory service years and use their excuse group appointment rights at the earliest opportunity. As a result of this, the case of a small number of experienced teachers in these regions emerges. The fact that, while the standard deviation of the answers given to the $6^{\text {th }}$ question of our research (I'm thinking of using my appointment right at the earliest opportunity due to terrorist incidents.) was 1.21 , that its arithmetic mean was 3.74 which is close to Agree supports this interpretation.

Finally, the effect of terrorist incidents on the teaching profession attitude did not show significant differences depending on the occupational status, and the principals, vice-principals, teachers' rates of being affected by terrorist incidents turned out to be close to each other.

\subsection{Suggestions}

Terror and conflict environment seriously affect education and training. Taking necessary precautions can be ensured by developing the sub-dimensions of the scale prepared on this subject, deepening the subject on the same or different variables, doing research with teachers working especially in the provinces and districts where terrorist incidents are very severe, and examining the subject in detail.

The social and economic rights of the teachers who serve in the Eastern and Southeastern regions, in other words, where the terror is dense, can be increased.

Teachers' worries about the subject should be eliminated with in-service seminars and their attitudes should be changed positively.

In order to minimize the number of the attacks made against schools, each school in the regions where terrorist incidents frequently occur should be kept guarded by law-enforcement officers day and night.

It can be ensured by the government that the teachers and students perform their education and training activities in safety by creating safe education areas for the students in the regions where the terrorist incidents are severe to not to fall behind on their education.

Improving the morale of the teachers serving in the regions where terrorist incidents frequently occur can be ensured by giving constant emotional support to them by the government officials, and the increase in their occupational attitudes can be ensured by emphasizing how much the students who receive an education there need teachers working in these regions.

\section{REFERENCES}

[1] Aşkar, P., \& Erden, M. (1987). Attitude Towards Teaching Profession Scale. Modern Education Journal 121 (12), 8-11.

[2] Bal, İ., \& Özkan, E. (2006). Chronology of PKK Terrorist Organization. International Law and Policy Journal, 2, 8, 146-156.

[3] Barutçu, D. (2010). The Effect of Terrorism on the Economic Development in Turkey Yüksek Lisans Tezi, Gazi Üniversitesi, Social Science Institution, Ankara.

[4] Baykara, K. (2008). A Study on Classroom Preservice Teachers' Socio-cultural Qualities and Attitudes Towards Teaching Profession]. Mersin University Faculty of Education Journal, 4, 2, 151-168.

[5] Çetin, Ş. (2006). Developing the Teaching Profession Attitude Scale (Validity and Reliability Study)]. Gazi University industrial Arts Education Journal, 18, 28-37.

[6] Bayar, A. (2013). Factors affecting teachers' participation in professional development activities in Turkey. Doctorate Dissertation. University of Missouri--Columbia, USA.

[7] Bayar, A. (2014). Satisfaction of teachers with mentoring programs in Turkey. Anthropologist. 18. 2, 299-308.

[8] Bayar, A. (2014). The Components of Effective Professional Development Activities in terms of Teachers' Perspective. International Online Journal of Educational Sciences 6.2, 319-327.

[9] Demircioğlu, E., \& Özdemir, M. (2014). Examination of the Attitudes of Faculty of Arts and Sciences Students Towards Teaching Profession by Various Variables]. Mersin University Faculty of Education Journal, 10, 3, 110-122.

[10] Demirel, Ö. (2004). The Art of Teaching. Pegem Yayıncılık, Ankara.

[11] Erkuş, A., Sanl1, N., Bağl1, M. T., \& Güven, K. (2000). Developing of the Attitude Towards Teaching Scale. Education and Science, 25, 27-32.

[12] İnceoğlu, M. (2010). Attitude Perception and Communication. Beykent University Publishing, İstanbul.

[13] Demirtaş, H., Cömert, M., \& Özer, N. (2011). Preservice Teachers' Self-Sufficiency Beliefs and Attitudes Towards Teaching Profession. Education and Science, 36, 159, 96-111.

[14] Kavcar, C. (1987). The Place of Higher Teacher Education School in Training Teachers. Teacher Education Organizations' Yesterday, Today, and Future Symposium, Ankara.

[15] Kısaç, İ. (2002). Teacher-Student Communication. (Ed. Emin Karip). Classroom Management. Pegem Yayıncılık, Ankara. 
[16] Korkmaz, G., \& Sadık, F. (2011). Examination of the Occupational Attitudes of Teachers Working in Elementary Schools in terms of Socio-Demographic Characteristics. Çukurova University social Science Institution Journal, 20, 1, 121-138.

[17] Küçük, D. (2012). Music Teachers' Attitudes Towards Music Teaching Profession. Dicle Üniversitesi Ziya Gökalp Faculty of Education Journal,, 19, 151-161.

[18] MEB. (2007). In the Memory of Our Martyrized Teachers. Access Date: 25 Kasim 2015, www.meb.gov.tr/belirligunler/sehitogretmenler/

[19] Mercan, S., \& Eğit, M. (2014). Teachers' Branch Attitude Relationship. International Turks Educational Science
Journal, 2, 2, 224-241.

[20] Metin, M. (2015). From Hypothesis to Application Scientific Research Methods in Education. 2. Bask1, Ankara :Pegem Akademi Yayıncilık.

[21] Semerci, Ç. (1999). Students' Attitude Towards Teaching Profession Scale. Education and Science, 23, 51-55.

[22] T.C. Resmi Gazete (1991) Anti-terrorism Legislation. (20843 Mükerrer), 12.04.1991,125 .

[23] Üstüner, M. (2006). Validity and Reliability Study of the Attitude Towards Teaching Profession Scale. Theory and Application Education Management, 45, 109-127. 